\title{
PENERAPAN TEKNOLOGI PEMUPUKAN PADI SAWAH DI PROVINSI BENGKULU
}

\section{APPLICATION OF FERTILIZING TECHNOLOGY ON PADDY RICE FIELD IN BENGKULU PROVINCE}

\author{
Herlena Bidi Astuti dan Wahyu Wibawa \\ Balai Pengkajian Teknologi Pertanian (BPTP) Bengkulu \\ E-mail: bidizafirah@yahoo.co.id
}

\begin{abstract}
Fertilizing is one of strategy to improve crops productivity because it provides nutrient for the plant. This paper aims to analyze the implementation of fertilizing technology for field rice. The study was conducted from May-July 2012 in four districts that were North Bengkulu, Central Bengkulu, South Bengkulu and Kepahiang. Data was collected by survey method using questionnaire to 261 respondents. Statistic analysis using Chi quadrate was used to analyze most frequent fertilizer farmer use. The study showed farmers prefer five fertilizers. The implementation of these five fertilizers was varied.majority of respondents (95\%) used urea. The second preferred fertilizer was NPK $(67.8 \%)$, followed by TSP $(59.7 \%), K C L(46.3 \%)$ and organic fertilizer (34.8\%). Implementation of organic fertilizer was highest in Kepahiang and South Bengkulu that also show highest land productivity.
\end{abstract}

Keywords: fertilization technology, field rice, rice productivity

\section{PENDAHULUAN}

Sampai saat ini ketergantungan masyarakat Indonesia terhadap padi masih sangat besar, dari total kalori yang dikonsumsi oleh masyarakat hampir 60\% dicukupi oleh beras (Pringadi dkk dalam Zahra, 2011) membuat padi menjadi salah satu tanaman pangan yang sangat penting di Indonesia. Di Provinsi Bengkulu padi merupakan tanaman pangan yang banyak diusahakan oleh rumah tangga dan beras masih menjadi bahan makanan pokok dan sumber kalori bagi sebagian besar penduduk. Rata-rata produksi padi sawah per hektar di Provinsi Bengkulu mencapai 4,04 ton perhektar dengan nilai produksi 491.901 ton (BDA, 2010).

Upaya untuk meningkatkan produksi pertanian (padi) telah banyak dilakukan baik oleh pemerintah, lembaga swadaya masyarakat, dan perguruan tinggi. Tetapi di dalam pelaksanaannya diperoleh fakta bahwa hasil potensial

52 | Herlena Bidi Astuti, Wahyu Wibawa, Penerapan Teknologi Pemupukan ... 
produksi padi berbeda dengan hasil nyata (riil) yang diperoleh petani. Perbedaan hasil ini (yield gap) secara garis besar disebabkan oleh dua faktor yaitu faktor non-teknis dan faktor teknis. Faktor non-teknis yaitu keadaan yang menghalangi petani untuk menggunakan teknologi yang direkomendasikan. Hal-hal tersebut meliputi: (i) pengetahuan petani sebagai indikatornya adalah pengalaman petani dalam berusahatani, (ii) prasarana transportasi sebagai indikatornya adalah jarak lahan garapan dengan tempat tinggal petani. Sedangkan faktor teknis sebagai indikatornya adalah ketersediaan air irigasi. Faktor non teknis dan faktor teknis tersebut akan mempengaruhi pertimbangan petani sebagai menajer untuk mengambil keputusan dalam penggunaan input seperti bibit, pupuk, tenaga kerja, dan obat-obatan. Dengan demikian faktor-faktor non teknis dan faktor teknis bekerja secara simultan (bersama-sama) akan menentukan petani dalam penggunaan pupuk, tenaga kerja efektif dan obat-obatan yang akan menentukan tingkat produksi dan produktivitas usahatani padi sawah (Laksmi dkk, 2012). Menurut Sembiring dalam Suhendrata (2008) keberhasilan peningkatan produksi padi lebih banyak disumbangkan oleh peningkatan produktivitas dibandingkan dengan peningkatan luas panen. Pada periode 1971 - 2006 peningkatan produktivitas memberikan kontribusi sekitar $56,1 \%$, sedangkan peningkatan luas panen dan interaksi keduanya memberikan kontribusi masing-masing 26,3\% dan 17,5\% terhadap peningkatan produksi padi. Salah satu faktor produksi yang sangat menentukan peningkatan produktivitas adalah pemupukan (Maryeni dkk, 2009). Tujuan dari penelitian ini adalah untuk mendiskripsikan karakteristik responden petani padi secara spasial menurut kabupaten yang menjadi wilayah penelitian dan mendiskripsikan rekomendasi pemupukan menurut wilayah serta menganalisis penerapan teknologi pemupukan di Provinsi Bengkulu

\section{METODE PENELITIAN}

\section{Waktu dan Lokasi}

Penelitian ini dilakukan pada bulan Mei sampai Juli tahun 2012 pada delapan desa sentra padi di empat kabupaten yang ada di Provinsi Bengkulu yaitu di Kabupaten Bengkulu Utara, Kabupaten Bengkulu Selatan, Kabupaten Bengkulu Tengah dan Kabupaten Kepahiang.

\section{Pengumpulan Data}

Data dikumpulkan dengan metode penelusuran pustaka dan metode survey menggunakan kuesioner pada 261 responden. Identitas responden meliputi umur, pendidikan, luas lahan dan anggota keluarga responden. Data pemupukan yang diambil adalah jumlah dan jenis pupuk yang diterapkan oleh 
petani baik itu pupuk organik maupun pupuk kimia seperti urea, NPK, KCL dan TSP/SP36.

\section{Metode Analisis Data}

Data karakteristik responden dan rekomendasi pemupukan dianalisis secara diskriptif. Untuk melihat jenis pupuk yang paling banyak diterapkan oleh petani digunakan uji statistik Chi Kuadrat $\left(X^{2}\right)$.

$$
\begin{array}{rlll}
X^{2}=\sum_{i=1}^{k} \frac{\left(f_{0}-f_{h}\right)^{2}}{f_{h}} & X^{2} & \text { Chi kuadrat } \\
f_{0} & = & \text { Frekuensi yang di observasi } \\
f_{h} & = & \text { Frekuensi yang diharapkan }
\end{array}
$$

Chi kuadrat yang digunakan adalah chi kuadrat satu sampel yang merupakan teknik statistic untuk menguji hipotesis bila dalam populasi terdiri atas dua atau lebih kelas di mana data berbentuk nominal dan jumlah sampelnya cukup besar (Sugiyono, 2011).

\section{HASIL DAN PEMBAHASAN}

\section{Karakteristik Responden}

Rata-rata umur petani di daerah penelitian paling tinggi adalah 40,9 tahun yaitu di Kabupaten Bengkulu Tengah, kemudian di Kabupaten Bengkulu Utara 40,4 tahun, di Kabupaten Bengkulu Selatan 39,7 tahun dan yang terakhir adalah di Kabupaten Kepahiang yaitu 39,4 tahun. Dari sini dapat dilihat bahwa petani masih terbilang usia produktif. Pada usia produktif kegiatan usahatani dapat dikerjakan secara optimal dengan curahan tenaga kerja fisik yang tersedia (Nuryanti dan Sahara, 2008). Rata-rata pendidikan petani responden paling tinggi adalah di Kabupaten Bengkulu Selatan yaitu 12,3 tahun kemudian Kabupaten Kepahiang 9,14 tahun, Bengkulu Tengah yaitu 9,11 tahun dan yang paling rendah di Kabupaten Bengkulu Utara yaitu 8,5 tahun. Menurut Soekartawi (1988) semakin muda petani biasanya mempunyai semangat untuk ingin tahu apa yang belum mereka ketahui, sehingga mereka berusaha untuk lebih cepat melakukan adopsi inovasi walaupun sebenarnya mereka masih belum berpengalaman dalam soal adopsi inovasi tersebut, begitu pula pendidikan bahwa mereka yang berpendidikan tinggi adalah relatif lebih cepat dalam melaksanakan adopsi teknologi dan sebaliknya mereka yang berpendidikan rendah agak sulit untuk melaksanakan adopsi inovasi dengan cepat. Tingkat pendidikan dapat mempengaruhi pola pikir dan daya nalar seseorang biasanya seseorang yang mengenyam pendidikan cukup lama akan lebih rasional dalam bertindak dan menjalankan usahanya. Kondisi pendidikan 
petani daerah penelitian memberikan harapan bagi penerapan teknologi pertanian.

Tabel 1. Karakteristik Petani Padi di Empat Kabupaten di Provinsi Bengkulu

\begin{tabular}{clcccc}
\hline No & Kabupaten & Umur & Pendidikan & $\begin{array}{c}\text { Luas } \\
\text { lahan }\end{array}$ & $\begin{array}{c}\text { Agt } \\
\text { keluarga }\end{array}$ \\
\hline 1 & Bengkulu Utara & 40,4 & 8,5 & 1,02 & 4 \\
2 & Bengkulu Selatan & 39,7 & 12,3 & 0,85 & 4 \\
3 & Bengkulu Tengah & 40,9 & 9,11 & 1,53 & 4 \\
4 & Kepahiang & 39,4 & 9,14 & 0,75 & 4 \\
\hline
\end{tabular}

Sumber: data primer diolah, 2013

Rata-rata luas lahan sawah garapan petani responden didaerah penelitian paling tinggi adalah di Kabupaten Bengkulu Tengah yaitu 1,53 ha selanjutnya di Bengkulu Utara 1,02 ha, Bengkulu selatan 0,85 ha dan yang paling rendah yaitu di Kabupaten Kepahiang 0,75 ha. Penguasaan lahan sawah garapan disemua kabupaten cukup tinggi, menurut hasil penelitian Wangke dkk (2011) luas lahan garapan petani berhubungan signifikan dengan tingkat penerapan teknologi usahatani padi sawah, petani yang menggarap lahan yang lebih luas cenderung masuk kategori tinggi dalam penerapan teknologi usahatani padi sawah.

Jumlah anggota keluarga sangat mempengaruhi ketersediaan tenaga pertanian yang berarti menghemat biaya tenaga kerja atau biaya produksi. Sudalmi (2009) menjelaskan bahwa tenaga kerja merupakan faktor penting dalam usahatani, khususnya faktor tenaga kerja petani dan para anggota keluarganya. Petani dalam setahun tidak selalu disibukkan dalam kegiatan usahataninya. Tetapi ada waktu-waktu luang dan ada waktu-waktu sibuk. Pada waktu sibuk apabila tenaga keluarga tidak mencukupi maka petani mencari tenaga kerja luar keluarga atau tenaga kerja upahan. Berarti tenaga kerja dalam keluarga merupakan tenaga kerja utama jika sudah tidak mencukupi barulah petani akan mencari tenaga kerja luar keluarga. Dari hasil penelitian Wahyuningsih (2012) diketahui persentase tenaga kerja dalam keluarga terhadap total tenaga kerja rata-rata $79,49 \%$ dan persentase tenaga kerja luar keluarga 20,51\% dan kontribusi tenaga kerja dalam keluarga terhadap pendapatan usaha tani adalah sebesar 20,1\%. Pada daerah penelitian rata-rata anggota keluarga disemua kabupaten cukup sedikit yaitu 4 orang hal ini bisa membuat penyerapan tenaga kerja luar keluarga dan biaya tenaga kerja menjadi besar tetapi biaya hidup rumah tangga petani bisa lebih ringan karena semakin banyak jumlah anggota keluarga yang menjadi tanggungan berarti semakin besar pula kebutuhan rumah tangga (Sondakh dan Matindas, 2006). 


\section{Rekomendasi Pemupukan}

Jumlah pupuk yang direkomendasikan setiap kabupaten berbeda-beda. Untuk provinsi Bengkulu urea merupakan jenis pupuk yang direkomendasikan paling banyak yaitu 200 - $250 \mathrm{~kg} / \mathrm{ha}$. Nitrogen yang terkandung dalam pupuk urea bersifat mobile, mudah tercuci oleh air hujan atau menguap karena panas matahari, sehingga diperlukan cara pemupukan yang benar supaya terserap dengan baik oleh tanaman. Pada sisi lainnya pupuk nitrogen sangat diperlukan tanaman karena ketersediaannya terbatas dan esensial bagi pertumbuhan tanaman (Suwarto, 2008). Pupuk urea akan berpengaruh nyata terhadap produksi padi sawah, dimana penggunaan pupuk urea pada usahatani padi dapat meningkatkan produksi $0,093 \%$ untuk setiap penambahan 1\% pupuk urea (Laksmi dkk, 2012).

Tabel 2. Rekomendasi Pemupukan Berdasarkan Permentan No 40 Tahun 2007

\begin{tabular}{clccc}
\hline No & Kabupaten & Urea $(\mathrm{kg} / \mathrm{ha})$ & KCL $(\mathrm{kg} / \mathrm{ha})$ & SP-36 (kg/ha) \\
\hline 1 & Bengkulu Utara & 200 & 50 & 75 \\
2 & Bengkulu Selatan & 250 & 100 & 100 \\
3 & Bengkulu tengah & 200 & 50 & 50 \\
4 & Kepahiang & 250 & 50 & 75 \\
\hline
\end{tabular}

Sumber: Permentan 2007

Selain pemupukan kimia, pemupukan dari bahan organik juga bisa meningkatkan produktivitas cukup signifikan. Pemanfaatan pupuk organik paling banyak di Kabupaten Kepahiang dan Bengkulu Selatan, dimana produktivitas lahan juga paling tinggi di dua kabupaten ini dan sebaliknya di Bengkulu Utara pemanfaatan pupuk organik paling rendah hasil produktivitas lahannyapun paling rendah. Pemberian pupuk bokashi 30 ton/ha dan NPK organik $600 \mathrm{~kg} /$ ha pada tanaman padi sawah dapat meningkatkan penyerapan $\mathrm{N}$, P, dan K pada setiap tanaman, hal ini bisa terjadi karena kondisi tanah menjadi relatif lebih baik dibandingkan tanpa pemberian pupuk sehingga perakaran tanaman berkembang lebih baik dan mampu meningkatkan serapan hara N, P dan K (Rambe, 2010). Bokashi mengandung mikroorganisme tanah efektif mempercepat proses dekomposisi bahan organik dalam tanah, sehingga dapat meningkatkan ketersediaan unsur hara N,P dan K bagi tanaman (Zahra, 2011). Bahan organik berupa kompos atau pupuk kandang atau jerami padi sangat penting untuk menyuburkan lahan, pemberian 2 ton/ha pupuk kandang atau 5 ton/ha pupuk jerami bisa mengurangi pemanfaatan pupuk kimia. Kompos atau pupuk kandang yang disebarkan dilahan sebelum pengolahan lahan yang terakhir atau dengan mengembalikan jerami ke lahan bisa menghemat penggunaan pupuk KCL hingga < $50 \mathrm{~kg}$ per hektar. Penggunaan pupuk organik ini juga mampu menekan penggunaan pupuk kimia $30 \%$ dan jika pemupukan organik dilakukan terus menerus maka mampu mengurangi penggunaan pupuk kimia hingga 50\% (Rambe, 2010).

56 | Herlena Bidi Astuti, Wahyu Wibawa, Penerapan Teknologi Pemupukan ... 


\section{Penerapan Teknologi Pemupukan}

Pemupukan merupakan suatu upaya menambah atau menyediakan semua hara penting untuk kebutuhan tanaman padi sehingga tanaman dapat tumbuh optimal, pemupukan harus tepat jenis, dosis dan waktu (Wibawa, 2010). Pemanfaatan pupuk organik maupun kimia sudah banyak dilakukan oleh petani meliputi pupuk urea, TSP, KCL dan NPK namun belum menerapkan sesuai dengan rekomendasi sehingga pemupukan menjadi tidak seimbang.

Dari hasil uji statistik Chi kuadrat dengan $a=0,05$ didapatkan hasil bahwa penerapan dari lima jenis pupuk di tingkat petani tidak sama. Pupuk urea merupakan pupuk yang paling banyak digunakan yaitu oleh 95\% responden kemudian pupuk yang kedua yang paling banyak digunakan adalah pupuk NPK 67,8\% responden, pupuk TSP 59,7\% responden, pupuk KCL 46,3\% respoden, dan yang paling sedikit diterapkan dalam pemupukan padi sawah adalah pupuk organik $34,8 \%$ responden. Dalam penelitian Supriady R (2009), Koefisien pupuk urea pada analisis per usahatani sebesar 0,0361 (signifikan secara statistik pada tingkat kesalahan 1\%), yang menunjukkan usahatani padi sawah ada respon terhadap dosis pupuk yang digunakan sebesar 113,35 kg/ha nilai koefisien regresi sebesar 0,0383 yang mempunyai arti bahwa setiap penambahan pupuk urea sebesar $100 \%$ akan diikuti dengan kenaikan produksi padi GKG sebesar 3,83\%.

Setelah urea, jenis pupuk yang paling banyak diterapkan oleh petani adalah pupuk NPK. Unsur hara N, P, dan K termasuk unsur hara makro yang dibutuhkan dalam jumlah banyak dan mutlak harus ada. Peranan utama unsur $\mathrm{N}$ bagi tanaman adalah untuk merangsang pertumbuhan secara keseluruhan, khususnya batang, cabang, dan daun. Selain itu N berperan penting dalam pembentukan hijau daun yang sangat berfungsi dalam proses fotosintesis. Unsur $\mathrm{P}$ bagi tanaman berguna untuk merangsang pertumbuhan akar, khususnya akar benih dan tanaman muda serta mempercepat pembungaan, pemasakan biji dan buah. Unsur K juga merupakan sumber kekuatan bagi tanaman dalam menghadapi kekeringan dan penyakit (Lingga dan Marsono, 1999).

KCL dan TSP merupakan jenis pupuk kimia yang tidak begitu banyak diterapkan oleh petani begitu juga dengan pupuk organik yang diterapkan oleh petani paling sedikit. Kalium pada pupuk KCL sangat dibutuhkan oleh tanaman padi karena kalium membantu pembentukan protein dan karbohidrat, mengeraskan jerami, meningkatkan resistensi tanaman terhadap penyakit dan meningkatkan kualitas biji/buah (Isyanto, 2012). Begitu juga dengan pupuk organik sangat berguna bagi kelangsungan kualitas lahan usahatani, pemberian bahan organik sangat dianjurkan untuk memelihara kesuburan tanah. Peran bahan organik tidak hanya memperbaiki kesuburan 
kimia tetapi sekaligus dapat meningkatkan kesuburan fisik dan biologi tanah (Rusly, 2009).

Tabel 3. Penerapan Pemupukan Dan Produktivitas Lahan Di Kabupaten Bengkulu Utara, Bengkulu Selatan, Bengkulu Tengah Dan Kepahiang

\begin{tabular}{llrrrrrr}
\hline No & Kabupaten & $\begin{array}{c}\text { Urea } \\
(\mathrm{kg} / \mathrm{ha})\end{array}$ & $\begin{array}{c}\text { NPK } \\
(\mathrm{kg} / \mathrm{ha})\end{array}$ & $\begin{array}{c}\text { TSP } \\
(\mathrm{kg} / \mathrm{ha})\end{array}$ & $\begin{array}{c}\text { KCL } \\
(\mathrm{kg} / / \mathrm{ha})\end{array}$ & $\begin{array}{c}\text { Organik } \\
(\mathrm{kg} / \mathrm{ha})\end{array}$ & $\begin{array}{r}\text { Produktivi- } \\
\text { tas }(\mathrm{kg} / \mathrm{ha})\end{array}$ \\
\hline 1 & Bengkulu Utara & 143,5 & 138,4 & 111,4 & 68,9 & 263,0 & 3.281 \\
2 & Bengkulu Selatan & 156,9 & 117,6 & 81,8 & 84,5 & 171,4 & 3.864 \\
3 & Bengkulu Tengah & 90,5 & 78,1 & 91,5 & 88,0 & 332,3 & 3.555 \\
\hline 4 & Kepahiang & 147,6 & 89,8 & 77,7 & 72,7 & 527,6 & 4.252 \\
\hline
\end{tabular}

Sumber: data primer diolah, 2013

Dari Tabel 3 dapat dilihat bahwa produktivitas lahan sawah paling tinggi di Kabupaten Kepahiang yaitu $4.252 \mathrm{~kg} / \mathrm{ha}$ kemudian produktivitas lahan terbanyak kedua di Kabupaten Bengkulu Selatan yaitu $3.864 \mathrm{~kg} / \mathrm{ha}$, yang ketiga di Kabupaten Bengkulu Tengah sebanyak $3.555 \mathrm{~kg} / \mathrm{ha}$ sedangkan produktivitas yang terendah di Kabupaten Bengkulu Utara yaitu $3.281 \mathrm{~kg} / \mathrm{ha}$. Produktivitas padi sawah tidak hanya dipengaruhi oleh pemupukan, pemanfaatan teknologi yang tepat dari berbagai faktor produksi juga sangat berpengaruh. Sejalan dengan hasil penelitian Isyanto (2012) di Kabupaten Ciamis penggunaan faktor produksi, lahan dan pelatihan yang diikuti oleh petani juga berpengaruh signifikan terhadap produksi padi. Penggunaan benih dan pupuk organik tidak berpengaruh atau bernilai negative yang artinya penggunaan benih dan pupuk organik harus dikurangi, walaupun ketika pupuk organik yang diterapkan bersamaan dengan pupuk kimia bisa meningkatkan produksi padi sawah. Di Kabupaten Seluma Bengkulu, efisiensi faktor produksi pupuk urea, pupuk NPK dan benih memiliki nilai indek efisiensi lebih dari 1 yang mana faktor produksi ini masih dapat di tingkatkan penggunaannya untuk meningkatkan hasil produksi (Hamdan, 2013). Di Kabupaten Kendal pupuk $\mathrm{P}$ dan pupuk $\mathrm{K}$ menunjukkan pengaruh yang signifikan artinya banyak sedikitnya penggunaan ketiga faktor produksi tersebut akan mempengaruhi output produksi padi, semakin banyak jumlah pupuk $\mathrm{P}$ dan $\mathrm{K}$ yang digunakan hasil yang diperolehpun akan meningkat, sedangkan pupuk $\mathrm{N}$ mempunyai pengaruh negatif yang artinya penambahan pupuk N dapat menurunkan produksi padi (Buharman dan Nurnayetti, 2011). 


\section{SIMPULAN DAN SARAN}

\section{Simpulan}

Karakteristik petani meliputi: umur, masih berada pada usia produktif, pendidikan cukup, lahan garapan di atas 0,5 ha dan anggota keluarga rata-rata 4 orang. Kondisi karakteristik petani cukup baik untuk dapat menerima dan menerapkan inovasi teknologi pertanian. Dalam penerapan pemupukan petani belum mengikuti anjuran kementerian pertanian. Pupuk urea adalah jenis pupuk yang paling banyak digunakan oleh petani diikuti dengan penerapan pupuk NPK, TSP, KCL dan yang terakhir adalah pemanfaatan pupuk organik.

\section{Saran}

Perlu dilakukan pendampingan dan penyuluhan pada petani untuk melakukan pemupukan sesuai dengan kebutuhan pertumbuhan tanaman. Penyuluh atau pihak terkait lebih giat mensosialisasikan pentingnya pemanfaatan pupuk organik untuk menjaga kualitas lahan.

\section{DAFTAR PUSTAKA}

Buharman, B., dan Nurnayetti. 2011. Dinamika Indikator Kesejahteraan Petani Pedesaan di Sumatera Barat. Jurnal Pengkajian dan Pengembangan Teknologi Pertanian. Volume 14 No 2. Hal 121-130.

Hamdan. 2013. Analisis Efisiensi Faktor Produksi pada Usahatani Padi Sawah di Bengkulu. Prosiding hal 252 - 259.

Isyanto, Y. Agus. 2012. Faktor-faktor yang Berpengaruh terhadap Produksi pada Usahatani Padi di Kabupaten Ciamis. Jurnal Cakrawala Galuh. Volume 1 No.8.

Laksmi, Citra NMA, Suamba dan Ambarawati. 2012. Analisis Efisiensi Usahatani Padi Sawah (Studi Kasus di Subak Guama Kecamatan Marga Kabupaten Tabanan). E-Journal Agribisnis dan Agrowisata volume 1 no 1. Hal 34 44.

Lingga, P., dan Marsono. 1999. Petunjuk Penggunaan Pupuk. Penebar Swadaya. Jakarta.

Maryeni, R., dkk. 2009. Teknologi Pemanfaatan Limbah Buah Kakao sebagai Pupuk Organik Ramah Lingkungan di Nagari Kamang Hilir Kecamatan Kamang Magek Kabupaten Agam. WWW.Respository.unand.ac.id/3286/1/renimaryeni.pdf. 
Nuryanti dan Sahara. 2008. Analisa Karakteristik Petani dan Pendapatan usahatani Kakao di Sulawesi Tenggara. SOCA Volume 8 Nomor 3.

Rambe, Sri Suryani. 2010. Pemupukan Padi Sawah. Panduan Teknologi Mendukung Program PUAP. Balai Pengkajian Teknologi Pertanian Bengkulu (BPTP).

Rusly, Supriady. 2009. Analisis Pemanfaatan Faktor Produksi pada Usahatani Padi Sawah di Kabupaten Konawe Sulawesi Tenggara. Jurnal Aplikasi Manajemen. Volume 7 No 2. Hal 274-283.

Soekartawi. 1988. Prinsip Dasar Komunikasi Pertanian. Penerbit Jakarta: Universitas Indonesia (UI-Press).

Sondakh, J., dan Matindas L. 2006. Karakteristik Dan Analisis Finansial Usaha Tani Kelapa (cocos nucifera) Di Sulwesi Utara. (Studi Kasus Petani Desa Pinili dan Klabat Kabupaten Minahasa Utara). Widyariset Vol 9 No 3. Hal 131-140.

Sudalmi, S.E. 2009. Analisis Penggunaan Tenaga Kerja Pertanian pada Usahatani Padi Sawah (Study Kasus di Desa Karang Duren). INNOFARM : Jurnal Inovasi Pertanian Volume 8. Hal 8 - 19.

Sugiyono. 2011. Statistik Untuk Penelitian. Afabeta. Bandung.

Suhendrata, T. 2008. Peran Inovasi Teknologi Pertanian dalam Peningkatan Produktivitas Padi Sawah untuk Mendukung Ketahanan Pangan. Prosiding Nasional Teknik Pertanian. Hal 1-15.

Suwarto. 2008. Produktivitas lahan Dan Biaya Usahatani Tanaman Pangan Di Kabupaten Gunung Kidul. Jurnal Ekonomi Pembangunan. Volume 9 nomor 2. Hal 168-183

Wahyuningsih, M.Y. 2012. Potensi Tenaga Kerja dalam Keluarga Terhadap Pendapatan Usahatani Tomat (Lycopersicon esculetium L) di Desa Rantau Keminting Kecamatan Labuan Amas Utara Kabupaten Hulu Sungai Tengah Provinsi Kalimantan Selatan. Media Sains, Volume 4 Nomor 1 hal 92-95.

Wangke. M.W., Suzana dan Hermia Siagian. 2011. Penerapan Teknologi Usahatani Padi Sawah di Desa Sendangan Kecamatan Kakas Kabupaten Minahasa. ASE-Volume 1 no 1. Hal 53-57.

Wibawa, W. 2010. Budidaya Padi Sawah Dengan Pendekatan Pengelolaan Tanaman dan Sumberdaya Terpadu (PTT). Panduan Teknologi Mendukung Program PUAP. Balai Pengkajian Teknologi Pertanian Bengkulu (BPTP).

Zahra, S. 2011. Aplikasi Pupuk Bokashi dan NPK Organik pada Tanah Ultisol Untuk Tanaman Padi Sawah dengan Sistem SRI (System of Rice Intensification). Jurnal Ilmu Lingkungan PPS Universitas Riau. 5 (2): 114-128.

60 | Herlena Bidi Astuti, Wahyu Wibawa, Penerapan Teknologi Pemupukan ... 